\title{
Synthesis and Characterization of Some Seven Coordinated Complexes of Lanthanide(iii) Perchlorates with 4-[n-(4- Ethylbenza-lideneamino)]- Antipyrine Semicarbazone as Primary Ligand and Pyridine as Secondary Ligand
}

\author{
SANJAY DUTT KAUSHIK \\ Department of Chemistry, Lajpatrai Postgraduate College, Sahibabad-201005 (Ghaziabad). \\ ${ }^{*}$ Corresponding author E-mail: sdkaushik.11@gmail.com \\ http://dx.doi.org/10.13005/ojc/330521 \\ (Received: July 12, 2017; Accepted: August 14 , 2017)

\begin{abstract}
Mixed ligands complexes of lanthanide(III) perchlorates obtained from 4-[N(ethylbenzalideneamino)]-antipyrine semicarbazone (ebaaps) as primary ligand and pyridine(py) as secondary ligand have been synthesized and characterized. The analytical studies on these compounds include elemental analyses, molecular weight determination, molar conductance, and magnetic susceptibility, infrared and electronic spectra. The primary ligand, (ebaaps), in these complexes behaves as neutral tridentate $(\mathrm{O}, \mathrm{N}, \mathrm{N})$ while the secondary ligand pyridine $(p y)$ acts as unidentate nitrogen donor. The general composition of these complexes may be given as $\left[\mathrm{Ln}(\text { ebaaps })_{2} \cdot \mathrm{py}\right](\mathrm{ClO} 4)_{3}$, [ $\mathrm{Ln}=\mathrm{La}, \mathrm{Pr}, \mathrm{Nd}, \mathrm{Sm}, \mathrm{Gd}, \mathrm{Tb}$, Dy or Ho]. The values of nephelauxetic effect $(\beta)$, covalence factor $\left(b^{1 / 2}\right)$, Sinha parameter $(\delta \%)$ and the angular overlap parameter $(\eta)$ of the complexes have been calculated, and their thermal stabilities worked out by TGA.
\end{abstract}

Keywords: Lanthanide (III) Complexes, Semicarbazone, Pyridine, Characterization.

\section{INTRODUCTION}

Lanthanide ions attach special importance in coordination and bioinorganic chemistry. The study of lanthanide(III) complexes with heterocyclic compounds, bearing nitrogen, oxygen or sulphur, as ligand, has attracted increasing attention ${ }^{1-5}$. Lanthanide ions, in view of their particular electronic configuration and size are often used as a spectroscopic probe, surrogating for calcium(II) ions, in the studies of biological systems, as promoters in the dyeing industry, and as diagnostic agent in chemicals acting as medicine $e^{6-8}$. Pyrazolone ( $\mathrm{N}$-heterocyclic compound) is an active moiety, serving as a pharmaceutical ingredient of many nonstereoidal anti-inflammatory agents used in the treatment of arthritis and other musculoskeletal and joints disorders. Literature reveals that certain drugs showed increased activity when administered in the form of its metal chelates compared to the virgin form. The complexing behavior of 4-aminoantipyrine has been modified into a flexible ligand system by condensing it with a variety of reagents ${ }^{9-13}$. A number of reports are 
available on the coordination abilities of thiosemicarbazones of 4-aminoantipyrine $\mathrm{e}^{14-16}$ with different metal ions but comparatively less is known about the mixed ligand complexes of lanthanide(III) ions with substituted 4-aminoantipyrine. The present study reports the synthesis and characterization of some seven coordinated complexes of lanthanide (III) perchlorates with 4[N-(4'-ethylbenzalidene -amino)antipyrine semicarbazone (ebaaps) (Fig.1) as primary ligand, and pyridine as secondary ligand.

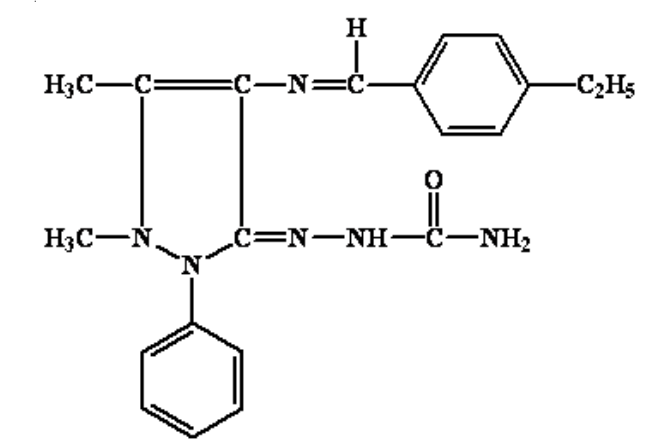

Fig.1.4-[N-(4'-ethylbenzalidene) amino]-antipyrine semicarbazone.

EXPERIMENTAL

The lanthanide(III) oxides were procured from Rare Earth Products Ltd. (India). The lanthanide perchlorates were prepared by heating the corresponding oxides with perchloric acid and then evaporating off the excess of $\mathrm{acid}^{17}$.The ligand ebaaps was synthesized as reported in the literature ${ }^{18}$. The commercial pyridine obtained (a C.D.H. product) was used after distillation.

All the complexes were synthesized by a general procedure. A solution of $\mathrm{Ln}\left(\mathrm{ClO}_{4}\right)_{3}(2 \mathrm{mmol})$, ebaaps $(4 \mathrm{mmol})$ and pyridine $(2 \mathrm{mmol})$ in absolute ethanol was refluxed for 2-3 $\mathrm{h}$. The precipitated product collected after concentrating and cooling the hot solution was filtered, washed first with ethanol and then with diethyl-ether, and finally dried in an oven at $100^{\circ} \mathrm{C}$ to an yield of $70-80 \%$.

\section{Analysis}

The lanthanide metal content was estimated as its oxide by direct combustion of the complex in a platinum crucible. Percentage of nitrogen was determined by Kjeldahl method. The perchlorate content was estimated by the Kurz's method. The molecular weight of the complexes was determined cryoscopically in freezing $\mathrm{PhNO}_{2}$ system using Beckmann thermometer of $\pm 0.01^{\circ} \mathrm{C}$ accuracy in. The conductivity measurements were carried on a Toshniwal Conductivity Bridge (Type CL01/01) with a dip-type cell operated at 220 volts $\mathrm{AC}$ mains; all the measurements being done at room temperature in $\mathrm{PhNO}_{2}$. The magnetic measurements were carried out at room temperature with a Gouy's balance using anhydrous copper sulphate as a calibrant. The infrared spectra of the complexes were recorded on a Perkins Elmer Infrared Spectrophotometer (Model 521) in $\mathrm{KBr}$ over a range of $4000-200 \mathrm{~cm}^{-1}$. A Hilger Unispek Spectrophotometer with $1 \mathrm{~cm}$ quartz cell was used for recording the visible spectra of $\mathrm{Pr}^{3+}, \mathrm{Nd}^{3+}, \mathrm{Sm}^{3+}$ and $\mathrm{Ho}^{3+}$ complexes. Thermogravimetric analysis of the complexes was carried out in static air, using an open sample holder and $\mathrm{s}$ small platinum boat, maintaining a heating rate of $6 \%$ minutes.

\section{RESULTS AND DISCUSSION}

The analytical data of the complexes (Table.1) agree with the general composition $\mathrm{Ln}\left(\mathrm{ClO}_{4}\right)_{3}$. 2(ebaaps).py, ( $\mathrm{Ln}=\mathrm{La}, \mathrm{Pr}, \mathrm{Nd}, \mathrm{Sm}, \mathrm{Gd}$, $\mathrm{Tb}, \mathrm{Dy}$ or $\mathrm{Ho}$ ). That the complexes are anhydrous in nature is evidenced by their analytical, infrared and thermal studies. The complexes are generally soluble in common organic solvents but insoluble in diethyl-ether. The molar conductivity values of the complexes in nitrobenzene (Table.1) reveal that these complexes are 1:3 electrolytes. The effective magnetic moments (Table.1) of the complexes indicate that they are paramagnetic in nature except the $\mathrm{La}$ (III) complex which is diamagnetic. The observed magnetic moments of the complexes lie within the range predicted and observed in the complexes of paramagnetic ions as reported earlier ${ }^{19-20}$.

\section{Infrared spectra}

The infrared spectra of ebaaps, derived from 4-aminoantipyrine, are somewhat complex so as to designate various bands. Infrared absorptions of the ligand ebaaps have been assigned by comparing its spectrum with those of antipyrine and 4-aminoantipyrine, ${ }^{12,21,22}$ and some past reports 
Table. 1: Analytical, conductivity, molecular weight and magnetic data of lanthanide(III) nitrato complexes of ebaaps and pyridine.

\begin{tabular}{|c|c|c|c|c|c|c|}
\hline \multirow[t]{2}{*}{ Compounds (m.f.) } & \multicolumn{3}{|c|}{$\begin{array}{l}\text { Elemental analysis (\%) } \\
\text { Found (Calcd.) }\end{array}$} & \multirow[t]{2}{*}{$\begin{array}{l}\text { m.w. found } \\
\text { (calcd.) }\end{array}$} & \multirow[t]{2}{*}{$\begin{array}{l}\Lambda_{\mathrm{m}}\left(\mathrm{ohm}^{-1}\right. \\
\left.\mathrm{cm}^{2} \mathrm{~mol}^{-1}\right)\end{array}$} & \multirow[t]{2}{*}{$\mu_{\text {eff }}(B M)$} \\
\hline & Ln & $\mathbf{N}$ & $\mathrm{ClO}_{4}$ & & & \\
\hline $\begin{array}{l}\mathrm{La}\left(\mathrm{ClO}_{4}\right)_{3} \cdot(\text { ebaaps })_{2} \cdot p y \\
\left(\mathrm{C}_{47} \mathrm{H}_{53} \mathrm{~N}_{13} \mathrm{O}_{14} \mathrm{Cl}_{3} \cdot \mathrm{La}\right)\end{array}$ & $\begin{array}{c}10.88 \\
(10.95)\end{array}$ & $\begin{array}{c}14.22 \\
(14.34)\end{array}$ & $\begin{array}{l}23.32 \\
(23.53)\end{array}$ & $\begin{array}{c}318 \\
(1269)\end{array}$ & 80.2 & Diamag. \\
\hline $\begin{array}{l}\operatorname{Pr}\left(\mathrm{ClO}_{4}\right)_{3} \cdot(\text { ebaaps })_{2} \cdot p y \\
\left(\mathrm{C}_{47} \mathrm{H}_{53} \mathrm{~N}_{13} \mathrm{O}_{14} \mathrm{Cl}_{3} \cdot \mathrm{Pr}\right)\end{array}$ & $\begin{array}{l}1100 \\
(11.09)\end{array}$ & $\begin{array}{c}14.23 \\
(14.32)\end{array}$ & $\begin{array}{l}23.28 \\
(23.49)\end{array}$ & $\begin{array}{l}320 \\
(1271)\end{array}$ & 82.8 & 3.5 \\
\hline $\begin{array}{l}\mathrm{Nd}\left(\mathrm{ClO}_{4}\right)_{3} \cdot(\text { ebaaps })_{2} \cdot p y \\
\left(\mathrm{C}_{47} \mathrm{H}_{53} \mathrm{~N}_{13} \mathrm{O}_{14} \mathrm{Cl}_{3} \cdot \mathrm{Nd}\right)\end{array}$ & $\begin{array}{c}11.22 \\
(11.30)\end{array}$ & $\begin{array}{l}14.16 \\
(14.29)\end{array}$ & $\begin{array}{l}23.25 \\
(23.43)\end{array}$ & $\begin{array}{c}322 \\
(1274)\end{array}$ & 79.9 & 3.48 \\
\hline $\begin{array}{l}\mathrm{Sm}\left(\mathrm{ClO}_{4}\right)_{3} \cdot(\text { ebaaps })_{2} \cdot p y \\
\left(\mathrm{C}_{47} \mathrm{H}_{53} \mathrm{~N}_{13} \mathrm{O}_{14} \mathrm{Cl}_{3} \cdot \mathrm{Sm}\right)\end{array}$ & $\begin{array}{l}11.63 \\
(11.72)\end{array}$ & $\begin{array}{c}14.14 \\
(14.22)\end{array}$ & $\begin{array}{l}23.16 \\
(23.32)\end{array}$ & $\begin{array}{c}323 \\
(1280)\end{array}$ & 80.8 & 1.56 \\
\hline $\begin{array}{l}\mathrm{Gd}\left(\mathrm{ClO}_{4}\right)_{3} \cdot(\text { ebaaps })_{2} \cdot p y \\
\left(\mathrm{C}_{47} \mathrm{H}_{53} \mathrm{~N}_{13} \mathrm{O}_{14} \mathrm{Cl}_{3} \cdot \mathrm{Gd}\right)\end{array}$ & $\begin{array}{c}12.12 \\
(12.20)\end{array}$ & $\begin{array}{l}14.05 \\
(14.14)\end{array}$ & $\begin{array}{l}23.04 \\
(23.20)\end{array}$ & $\begin{array}{c}324 \\
(1287)\end{array}$ & 83 & 7.82 \\
\hline $\begin{array}{l}\mathrm{Tb}\left(\mathrm{ClO}_{4}\right)_{3} \cdot(\text { ebaaps })_{2} \cdot p y \\
\left(\mathrm{C}_{47} \mathrm{H}_{53} \mathrm{~N}_{13} \mathrm{O}_{14} \mathrm{Cl}_{3} \cdot \mathrm{Tb}\right)\end{array}$ & $\begin{array}{l}12.24 \\
(12.33)\end{array}$ & $\begin{array}{l}14.02) \\
(14.12)\end{array}$ & $\begin{array}{l}23.02 \\
(23.16)\end{array}$ & $\begin{array}{c}326 \\
(1289)\end{array}$ & 82.8 & 9.82 \\
\hline $\begin{array}{l}\mathrm{Dy}\left(\mathrm{ClO}_{4}\right)_{3} \cdot(\text { ebaaps })_{2} \cdot p y \\
\left(\mathrm{C}_{47} \mathrm{H}_{53} \mathrm{~N}_{13} \mathrm{O}_{14} \mathrm{Cl}_{3} \cdot \mathrm{Dy}\right)\end{array}$ & $\begin{array}{c}12.46 \\
(12.57)\end{array}$ & $\begin{array}{l}13.99 \\
(14.08)\end{array}$ & $\begin{array}{l}22.98 \\
(23.10)\end{array}$ & $\begin{array}{c}327 \\
(1292)\end{array}$ & 79.9 & 10.43 \\
\hline $\begin{array}{l}\mathrm{Ho}\left(\mathrm{ClO}_{4}\right)_{3} \cdot(\text { ebaaps })_{2} \cdot p y \\
\left(\mathrm{C}_{47} \mathrm{H}_{53} \mathrm{~N}_{13} \mathrm{O}_{14} \mathrm{Cl}_{3} \cdot \mathrm{Ho}\right)\end{array}$ & $\begin{array}{c}12.65 \\
(12.740\end{array}$ & $\begin{array}{c}13.96 \\
(14.05)\end{array}$ & $\begin{array}{l}22.94 \\
(23.05)\end{array}$ & $\begin{array}{c}329 \\
(1925)\end{array}$ & 81.3 & 10.52 \\
\hline
\end{tabular}

on semicarbazones ${ }^{20}$. In the ebaaps-Ln (III) complexes, the $\mathrm{n}\left(\mathrm{NH}_{-2}\right)$ of the hydrazinic nitrogen of semicarbazide (ca. $1622 \mathrm{~cm}^{-1}$ ) is absent in the infrared spectra of ebaaps, as expected. The amideII band is shifted towards the lower energy side as compared to that of the semicarbazone; this is due to a drift in the electron density from the hydrazinic nitrogen ${ }^{23}$. The characteristic absorption of the carbonyl group in ebaaps is observed at $1701 \mathrm{~cm}^{-1}$ ${ }^{24}$ while in the complexes, this band is shifted towards lower energy in the $1650-1640 \mathrm{~cm}^{-1}$ region (Table.2). The amide-II band in the free ebaaps is observed at $1566 \mathrm{~cm}^{-1}$ while in all the complexes, this band is also shifted towards lower wave numbers by $c a .30$ $\mathrm{cm}^{-1}$. These observations suggest coordination through the carbonyl oxygen atom. The strong band at $1602 \mathrm{~cm}^{-1}$ in ebaaps apparently has a large contribution from the $n(C=N)$ mode of the semicarbazone moiety ${ }^{25}$. This is found to suffer a blue shift in all the complexes. Another strong band observed at $1615 \mathrm{~cm}^{-1}$ is due to azomethine $(\mathrm{C}=\mathrm{N})$ absorption. On complexation, this band is found to shift towards the lower frequency region, clearly indicating the coordination through the azomethine
$-\mathrm{N}$ atom ${ }^{26-28}$. This discussion clearly indicates that ebaaps serves as a tridentate ligand, coordinating through the carbonyl-O, and the hydrzinic- $\mathrm{N}$ and azomethinic-N atoms.

Four strong absorptions occur in the infrared spectra of pyridine in the range 1650-1400 $\mathrm{cm}^{-1}$ which are attributed to $\mathrm{C}=\mathrm{C}, \mathrm{C}=\mathrm{N}$ stretchings and ring vibrations ${ }^{29,30}$. Out of these, the absorptions associated with the cyclic structure apparently remain unaffected on complexation while those arising from heterocyclic ring get shifted to higher frequencies due to tightening of the ring on coordination with $\mathrm{Ln}^{3+}$ ions. This suggest that pyridine is bonded to the $\mathrm{Ln}^{3+}$ ion through the hetero- $\mathrm{N}$ atom ${ }^{31,32}$. The bands due to $n(\mathrm{Ln}-\mathrm{O}) / \mathrm{n}(\mathrm{Ln}-\mathrm{N})$ are also observed in the far infrared region ${ }^{18}$. (Table.2).

In all the perchlorate complexes [Ln(ebaaps) $\left.)_{2} \cdot p y\right]\left(\mathrm{ClO}_{4}\right)_{3}$, only two strong $\mathrm{n}_{3}$ and $\mathrm{n}_{4}$ bands are observed in the 1098-1080 and 635-620 $\mathrm{cm}^{-1}$ regions respectively, due to $\mathrm{ClO}_{4}^{-}$. The presence of these bands indicate that the tetrahedral symmetry of the $\mathrm{ClO}_{4}^{-}$ion has not been disturbed on 


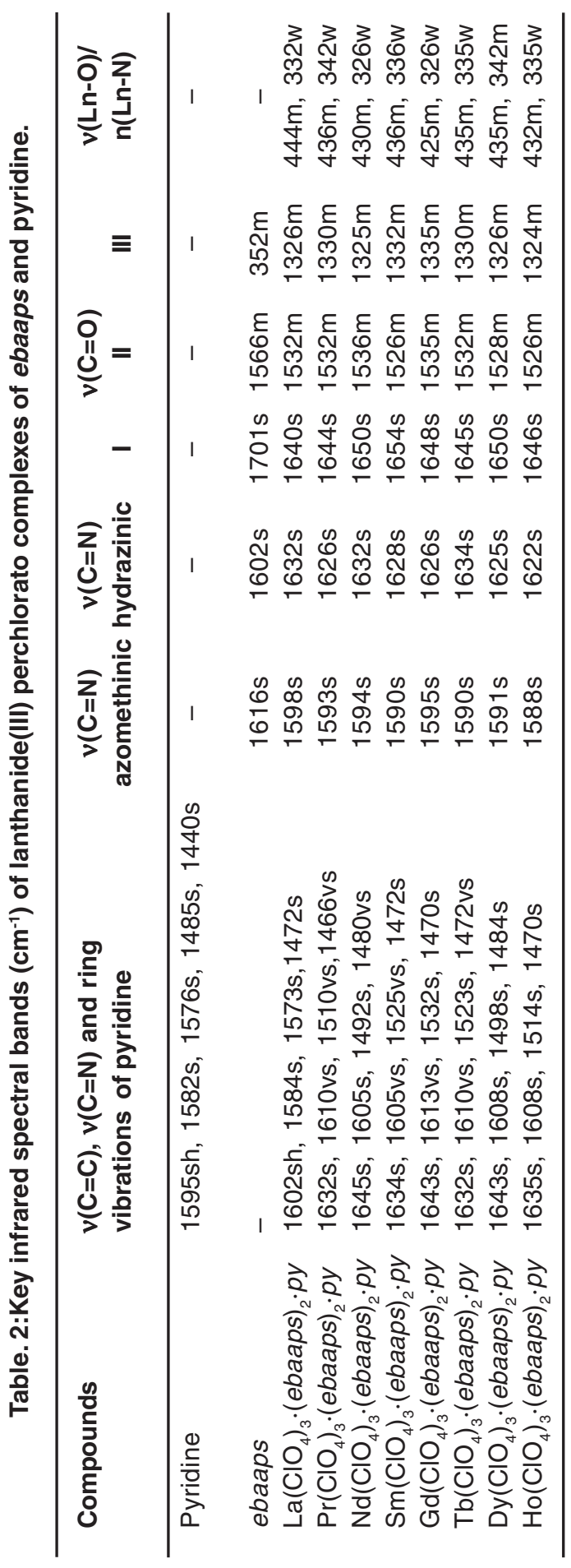

complexation and that these ions are not bonded to $\mathrm{Ln}^{3+}$ ions ${ }^{33,34}$. This conclusion is also supported by the conductance and molecular weight data.

\section{Electronic spectra}

Typical spectral data for the solutions of the mixed ligand complexes of lanthanide(III) perchlorates with ebaaps and pyridine are presented in Table. 4. The data for the aqueous salt solution are also given for comparison. Lanthanide (III) ion has no significant absorption bands in the visible region. However, the absorption bands for $\operatorname{Pr}(\mathrm{III}), \mathrm{Nd}(\mathrm{III}), \mathrm{Sm}$ (IIII), Gd(IIII) and Dy(III) ions appear in the visible and near infrared regions; this is due to the transitions from the ground levels of ${ }^{3} \mathrm{H}_{4},{ }^{4} \mathrm{I}_{9 / 2}$, ${ }^{6} \mathrm{H}_{5 / 2},{ }^{5} \mathrm{~S}_{7 / 2}$ and ${ }^{6} \mathrm{H}_{15 / 2}$ to the respective excited $\mathrm{J}$-levels of the $4 \mathrm{f}$-configurations. Some red shift or nephelauxetic effect is observed in the methylcyanide solutions of these complexes. This red shift is usually accepted as an evidence of a higher degree of covalency ${ }^{35}$. A marked enhancement in the intensity of the bands has been observed in all the complexes. This red shift of the hypersensitive bands has been utilized to calculate the nephelaxetic effect (b) in the complexes. The covalence factors, $b^{1 / 2}$ (values varies from 0.0340 0.0469), Sinha parameters (d \%) (0.05247-0.8898) (metal-ligand covalency per cent), and the covalency angular overlap parameter $(h)(0.0023$ 0.0044 ) of the complexes have been calculated from the respective $b$ value, $(0.09912-0.9954)^{36,37}$. The positive values of (1-b) and (d \%) in the complexes suggest that the bonding between the metal and the ligand is covalent compared to the bonding between the metal and an aqua ion. The positive values of bonding $\left(b^{1 / 2}\right)$ and angular overlap parameter (h) again indicate covalent bonding.

\section{Thermal studies}

The pyrolysis curves of some representative complexes [ $\mathrm{Ln}(\text { ebaaps })_{2}$ py] $\left(\mathrm{ClO}_{4}\right)_{3}$ $(\mathrm{Ln}=\mathrm{La}, \mathrm{Pr}, \mathrm{Sm}, \mathrm{Dy})$ show that the complexes are anhydrous in nature. The thermal curves indicate that there is mass loss (6.02-6.18 \%) in the 125$155^{\circ} \mathrm{C}$ temperature range due to the removal of pyridine. In the temperature range $240-280^{\circ} \mathrm{C}$, the mass loss (34.92-35.58\%) corresponds to one mole of ebaaps. At about $355^{\circ} \mathrm{C}$, the remaining ebaaps 


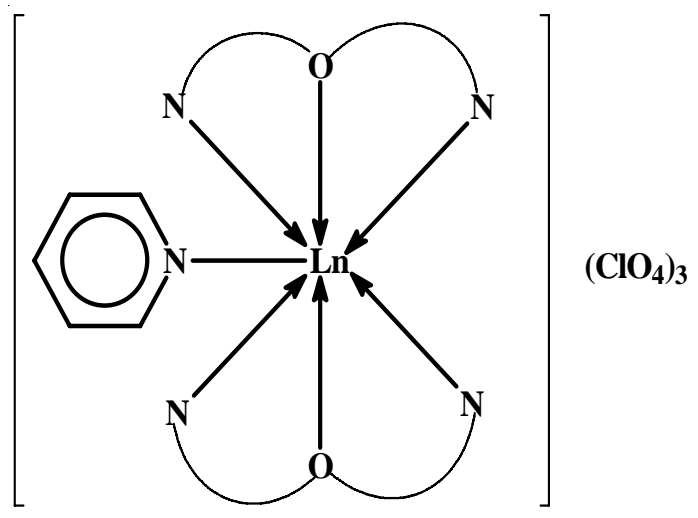

Fig. 2. General structure of $\left[\mathrm{Ln}(\text { ebaaps })_{2} \mathrm{py}\right]\left(\mathrm{ClO}_{4}\right)_{3}$, [Ln = La, Pr, Nd, Sm, Gd, Tb, Dy or Ho]. is also lost. The residue obtained after heating at about $835^{\circ} \mathrm{C}$ to a constant weight is very close to that expected for the lanthanide oxide ${ }^{38,39}$.

\section{Stereochemistry}

The molar conductance of the complexes observed in nitrobenzene indicates that they behave as 1:3 electrolytes. Hence, none of the three $\mathrm{ClO}_{4}^{-}$ions is bonded to the $\mathrm{Ln}^{3+}$ ion, and all are present outside the coordination sphere. ebaaps is a neutral tridentate $(\mathrm{O}, \mathrm{N}, \mathrm{N})$ ligand, and pyridine is coordinating to the central metal ion through its hetero $-\mathrm{N}$ atom. Thus, a coordination number of 7 is assigned to these complexes as shown below in a general structure of the complexes $^{40}$ (Figure. 2).

\section{REFERENCES}

1. Wang, M. , Xu Z.D. , Wang, L.F. and Xia, C.G. , Chem. Papers, 2002 56, 100.

2. Karthikeyan, G. , Mohanraj, K., Elango, K.P. and Kumar, K, Girish, Transition Met.-Chem., 2004, 29, 86.

3. Karthikeyen.G., Mohanraj.K. , Elango.K.P. and Girish Kumar.K. , Russ. J. Coord. Chem., 2006, 32, 380.

4. Wang.Y.B. and Shi.Y., Asia-Pacific Engineering and Technology Conference (APETC), 2017, 1144-1149.

5. Purohit.S. and Bhojak.N., Res. Rev. J. Chem.,2013, 2, 1-3.

6. Brittain.H.G., Richardson.F.S. and Martin.R.B., J. Am. Chem. Soc., 1976, 98, 9255.

7. H.G. Brittain, Inorg. Chem. 1979, 18, 17-40

8. Horrocks .W.D.W. (Jr.) and Sudnik.D.R. , J. Am. Chem. Soc., 1979, 101, 334 .

9. Maurya.R.C. , Mishra.D.D. , Pandey.M. , Shukla.P. and Rathour.R., Synth. React. Inorg. Met.-Org. Chem., 1992, 23, 161 .

10. Ismail.K.Z. , Dissouky.A.E. , Shehada.A.Z., Polyhedron, 16, 2909.

11. Agarwal.R.K. , Garg.P. ,Agarwal. H. and Chandra.S., Synth. React. Inorg. Met.-Org. Chem., 1997, 27251.

12. Agarwal.R.K. and Prakash.J., Polyhedron, 1991, 10, 2399.

13. Shankar.G., Prem Kumar.R.R. and Ramalingam. S. K., Polyhedron, 1986, 6, 991.
14. Chakraborti.I. , Asian J. Chem., 2003, 15, 16-23.

15. Chopra.J.R. ,Uppal.D., Arora.U.S. and . Gupta.S.K, Asian J. Chem., 2000, 12, 1277

16. Chakraborti.I. , Asian J. Chem., 2003, 15, 1795 .

17. Sandhu.S.S. and Aulakh.G.S., Indian J. Chem., 1973, 12, 348 .

18. Agarwal. R. K., Agarwal. H. and Manglik. A. K. Synth. React. Inorg. Met.-Org. Chem., 1996, 26, 1163 .

20. Agarwal. R. K. , Goel. Neetu and Sharma. A.K. , J. Indian Chem. Soc., 2001, 78, 39.

21. Agarwal. R. K., Srivastava. A. K. and Srivastava. T. N., Proc. Nat. Acad. Sci. (India), 1981, 51, 79.

22. Agarwal.R.K. and Rastogi.S.C. Thermochim. Acta, 1985 95, 279.

23. Levanon.H., J. Chem. Phys., 1968,49, 2031

24. Campbell.M.J.M. and Grzeskowick. R. , J. Inorg. Nucl. Chem., 1968, 30, 1865.

25. Dyer.J.F. , "Application of Absorption Spectroscopy of Organic Compounds", Prentice-Hall, New Delhi, 1984.

26. Agarwal.R.K. and Arora.K., Pol. J. Chem., 1993, 67, 219.

27. Agarwal.R.K., Prakash.J. and Chakraborti.I. Pol. J. Chem., 1993, 67, 1933.

28. Agarwal.R.K and Chakraborti.I., Pol. J. Chem., 1994, 68, 1085 . 
29. Singh.S.S., Indian J. Chem., 1969,7, 812 .

30. Singh.S.S., Naturforsch., 1969, 24, 2015 .

31. Agarwal.R.K. ,Srivastava.A.K., Srivastava.M. Bhakru.N. and Srivastava.T.N. , J. Inorg. Nucl. Chem., 1980, 42, 1775 .

32. Srivastava.A.K., Agarwal. R. K., Srivastava, Veena Kapoor.M. and Srivastava.T.N., J. Inorg. Nucl. Chem., 1981 43, 1393.

33. Hathaway.B.J. and Underhill.A.E., J. Chem. Soc., 1961, 309.

34. Krishnamurthy. S. S. and Soundararajan. S., Can. J. Chem., 1969, 47, 995.
35. Jorgensen.C.K., Naturforsch., 1964,19,424 .

36. Sinha.S.P., Spectrochim. Acta, 1966, 22, 57 .

37. Tandon.S.P. and Mehta.P.C., J. Chem. Phys., 1970, 52, 5313 .

38. Vicentini.G., Umeda.K. and Giolito.I., An. Acad. Brasil. Clinc., 1977, 49, 143.

39. Agarwal.R.K. and Gupta.S.K., Pol. J. Chem., 1987, 61, 341 .

40. Koppikar. D.K., Sivapulliah. P.V., Ramakrishanan. L. and Soundararajan. S., Structure and bonding, 1978, 34, 135 . 